\title{
Acetyl hexapeptide-3 in a cosmetic formulation acts on skin mechanical properties - clinical study
}

\author{
Kassandra Azevedo Tadini, Daiane Garcia Mercurio, Patrícia Maria Berardo Gonçalves Maia \\ Campos* $^{*}$
}

Faculty of Pharmaceutical Sciences of Ribeirão Preto, University of São Paulo, Ribeirão Preto, SP, Brazil

\begin{abstract}
Acetyl hexapeptide-3 has been used in anti-aging topical formulations aimed at improving skin appearance. However, few basic studies address its effects on epidermis and dermis, when vehiculated in topical formulations. Thus, the objective of this study was to determine the clinical efficacy of acetyl hexapeptide- 3 using biophysical techniques. For this purpose, formulations with and without acetyl hexapeptide- 3 were applied to the ventral forearm and the face area of forty female volunteers. Skin conditions were evaluated after 2 and 4-week long daily applications, by analyzing the stratum corneum water content and the skin mechanical properties, using three instruments, the Corneometer ${ }^{\circledR} C M 825$, Cutometer ${ }^{\circledR}$ SEM 575 and Reviscometer ${ }^{\circledR}$ RV600. All formulations tested increased the stratum corneum water content in the face region, which remained constant until the end of the study. In contrast, only formulations containing acetyl hexapeptide-3 exhibit a significant effect on mechanical properties, by decreasing the anisotropy of the face skin. No significant effects were observed in viscoelasticity parameters. In conclusion, the effects of acetyl hexapeptide- 3 on the anisotropy of face skin characterize the compound as an effective ingredient for improving conditions of the cutaneous tissue, when used in anti-aging cosmetic formulations.
\end{abstract}

Uniterms: Acetyl hexapeptide-3/use in cosmetic formulations. Acetyl hexapeptide-3/clinical efficacy. Biophysical techniques. Anti-aging/cosmetics. Clinical efficacy. Cosmetics.

Acetil hexapeptídeo-3 tem sido utilizado como um ingrediente ativo em formulações tópicas antienvelhecimento para a melhoria da aparência cutânea. No entanto, poucos estudos avaliam seus efeitos na epiderme e derme, quando veiculado em formulações tópicas. Portanto, o objetivo desse estudo foi a determinação da eficácia clínica de acetil hexapeptídeo-3 utilizando técnicas de biofísica e de análise de imagem. Para tal, formulações contendo, ou não, acetil hexapeptídeo-3 foram aplicadas no antebraço volar e na face de voluntárias. As condições cutâneas foram avaliadas após duas e quatro semanas de aplicação diária das formulações, por meio da análise no conteúdo aquoso do estrato córneo e avaliação das propriedades mecânicas da pele, utilizando os equipamentos Corneometer ${ }^{\circledR}$ CM 825 , Cutometer ${ }^{\circledR}$ SEM 575 e Reviscometer ${ }^{\circledR} R V 600$. Todas as formulações avaliadas aumentaram o conteúdo aquoso do estrato córneo na face, o qual permaneceu constante até o fim do estudo. Por outro lado, somente as formulações contendo acetil hexapeptídeo-3 apresentaram efeito significativo nas propriedades mecânicas, por meio da diminuição da anisotropia da pele na face. Não foram observados efeitos significativos para os parâmetros de viscoelasticidade. Em conclusão, os efeitos de acetil hexapeptídeo-3 na pele caracteriza este peptídeo como um ingrediente ativo efetivo para a melhoria das condições cutâneas, quando utilizadas em formulações cosméticas.

Unitermos: Acetil hexapeptídeo-3/uso em cosméticos. Acetil hexapeptídeo-3/eficácia clínica. Antienvelhecimento/cosméticos. Cosméticos/formulação tópica/avaliação. Formulações tópicas/ antiidade.

\footnotetext{
*Correspondence: Patrícia M.B.G. Maia Campos. Faculdade de Ciências Farmacêuticas de Ribeirão Preto. Universidade de São Paulo. Av. do Café, s/n, - Monte Alegre, 14040-903 - Ribeirão Preto, SP, Brazil. E-mail: pmcampos@usp.br
} 


\section{INTRODUCTION}

In recent decades, cosmetic formulations have been developed and employed in the treatment or prevention of skin changes resulting from aging, such as loss of elasticity, dryness, formation of wrinkles and spots, thus, possible delaying invasive procedures such as plastic surgery. In this context, substances with anti-aging action have been proposed to delay the appearance of wrinkles or leaving them less visible. However, due to the high turnover in the cosmetic area, active substances and their cosmetic products are constantly available to commercial purposes without basic studies on the action mechanisms supporting their benefits (Hermanns-Lê et al., 2001).

The advances in the area of skin biology, such as the mechanisms involved in cell renewal, in skin aging and in the action of neuroendocrine receptors, have increased peptide importance. The skin is a neuroendocrine immune organ in which many different molecules operate in an autocrine-paracrine manner to guarantee tissue homeostatsis in physiological and pathophysiological condition (Sivilia et al., 2008; Takema et al., 1994). Due to their chemical structure, peptides may act in the hydration, skin protection and homeostasis, keeping cutaneous tissue healthy and with a young appearance.

On the other hand, the search in the dermatology area for non-toxic molecules that mimic the action of botulinum neurotoxin, has identified acetyl hexapeptide- 3 in a rational design program. An in vitro study demonstrated that acetyl hexapeptide-3 inhibits neurotransmitter release with a potency similar to that of botulinum neurotoxin, although as expected, it displayed much lower efficacy than the neurotoxin (Sivilia et al., 2008; Blanes-Mira et al., 2002).

However, there are few hardcore data about the effects of acetyl hexapeptíde- 3 on epidermis and dermis, when vehiculated in topical formulations, under actual conditions of use, mainly using objective measurements, which are an important tool in clinical efficacy studies.

It should be considered that knowledge about the use of the acetyl hexapeptide- 3 is just beginning and much remains to be learned. Thus, it is very important to elucidate the effects and prove the efficacy of this active ingredient, which is commonly used to improve the skin conditions because of the proposed antiaging activity. So, clinical objective studies to assess acetyl hexapeptide-3 efficacy in the skin should rely on non-invasive skin biophysical techniques, which are often used to evaluate cosmetic products under actual conditions of use in human skin (Haftek et al., 2008; Paye et al., 2007; Uhoda et al., 2002).
Furthermore, the results should contribute to a better understanding of the acetyl hexapeptide- 3 effects by three biophysical techniques, Corneometer ${ }^{\circledR} C M 825$, Cutometer ${ }^{\circledR}$ SEM 575 and Reviscometer ${ }^{\circledR}$ RV600, in terms of skin hydration, skin elasticity and viscoelasticity, and skin anisotropy, showing that the peptide is clinically efficient and also that its use is very important in cosmetic formulations, due to its antiaging effects.

In this context, the aim of this study was to determine the real benefits of acetyl hexapeptide- 3 on human skin, by analyzing the effects of a cosmetic formulation containing this active substance in terms of stratum corneum water content and skin mechanical properties.

\section{MATERIAL AND METHODS}

\section{Test formulations}

The vehicle formulation tested contained 3.5\% (w/w) C12-20 acid PEG-8 ester, 0.7\% (w/w), acrylate polymer, $2.5 \%(\mathrm{w} / \mathrm{w})$ octyl octanoate, $2.0 \%(\mathrm{w} / \mathrm{w})$ propylene glycol, $2.0 \%(\mathrm{w} / \mathrm{w})$ glycerin, $2.0 \%(\mathrm{w} / \mathrm{w})$ dimethicone DC 200/50CS, 7.5\% (w/w) blend of UVA/UVB sunscreen (fenilbenzimidazol sulfonic acid, benzophenone-4) and $0.8 \%(\mathrm{w} / \mathrm{w})$ blend of parabens and phenoxyethanol, Phenonip ${ }^{\circledR}$ (Nipa Labs, Wilmington, USA). The formulations were supplemented or not with Argireline ${ }^{\circledR}$ (solution containing $0.05 \%$ acetyl hexapeptide-3) to a concentration of $10 \%$. Acetyl hexapeptide-3 was kindly provided by Galena Química e Farmacêutica Ltda, Campinas, Brazil.

\section{Study protocol}

The study was approved by the Faculty of Pharmaceutical Sciences of Ribeirão Preto - USP Ethics Committee (CEP/FCFRP 60/2005).

Forty healthy female subjects 35-55 years old having skin Fitzpatrick types II, III and IV participated in this study after having given their written informed consent. Exclusion criteria were the presence of any dermatitis and/ or other skin or allergic disease and smoking. Volunteers were instructed not to apply any topical products to the test sites for 2 weeks before and during the study. The subjects were allowed to wash normally, but not to use other skin care products on their arms and face. They were asked to avoid getting a sun tan, although the formulations applied had sunscreens in their composition to avoid the effects of daily exposure to UV radiation.

Prior to all measurements, subjects remained in the room for at least 30 minutes in order to allow full 
skin adaptation to room temperature $\left(20 \pm 2{ }^{\circ} \mathrm{C}\right)$ and humidity (45-60\%). Applications sites were randomized in order to minimize anatomic functional bias. The hydration index was assessed using measurements of capacitance (Corneometer ${ }^{\circledast}$ CM825; Courage \& Khazaka, Koeln, Germany) and the skin elasticity and viscoelasticity by cutometry (Cutometer ${ }^{\circledR}$ SEM 575; Courage $\&$ Khazaka) and by resonance running time measurements (Reviscometer ${ }^{\circledR}$ RV600; Courage \& Khazaka). The skin properties were examined using a standardized study protocol.

After the baseline measurements, the subjects were instructed to apply $1.0 \mathrm{~mL}$ of the formulations with acetyl hexapeptide- 3 on the ventral region of one forearm and the vehicle on the other forearm, twice daily. Half the subjects applied the $1.0 \mathrm{~mL}$ of formulation containing acetyl hexapeptide- 3 on the full face and the other half, the vehicle. Measurements on forearms and cheeks were carried out 2 and 4 weeks after daily application, 10-15 hours after the last treatment. For the last measurement, the formulations were applied in the evening and the measurements were taken in the following day (Savica et al., 2004).

Specifically, the experiment was conducted with twenty volunteers who were divided in two groups:

Group 1: application of the vehicle in the left forearm and in the face, and vehicle supplemented with acetyl hexapeptide- 3 in the right forearm.

Group 2: application of the vehicle supplemented with acetyl hexapeptide- 3 in the left forearm and in the face, and of the vehicle in the right forearm.

\section{Instrumentation}

The stratum corneum water content was determined with a non-invasive, skin capacitance meter (Corneometer ${ }^{\circledR}$ $C M 825$, Courage \& Khazaka, Germany). The averaged values of twenty measurements were used for subsequent calculations (Dal'Belo, Gaspar, Maia Campos, 2006; Fluhr, Gloor, Lazzerini, 1999; Fluhr et al., 1999).

Mechanical properties of the skin were determined using two instruments, the Cutometer ${ }^{\circledR}$ SEM 575 (Courage $\&$ Khazaka, Germany) and Reviscometer ${ }^{\circledR}$ RV600 (Courage \& Khazaka, Germany).

The measurement with Cutometer ${ }^{\circledR}$ SEM 575 consisted of five consecutive cycles of a 2 s suction application period followed by a $2 \mathrm{~s}$ relaxation period. The suction load was 450 mbars. The method analyzed the following mechanical parameters: $\mathrm{Ua} / \mathrm{Uf}$, the ratio of total retraction to total distension, called gross elasticity; $\mathrm{Ur} / \mathrm{Ue}$, net-elasticity of the skin without viscous deformation; Uv/
$\mathrm{Ue}$, the ratio of viscoelastic to elastic distension and $\mathrm{Ur} /$ $\mathrm{Uf}$, the ratio of immediate retraction to total distension, called biological elasticity (Dobrev, 2000; Dobrev, 2002).

The Reviscometer ${ }^{\circledR} R V 600$ is an equipment based on resonance running time measurements (RRTM) of acoustical shockwaves (Takema et al., 1994; HermannsLê et al. 2001; Ruvolo ; Stamatas ; Kollias, 2007). RRTM measurements were taken in precise directions, according to Uhoda et al.(2002), analyzing the medium RRTM, the lowest and highest RRTM (RRTM max and RRTM min). The anisotropy defined as the ratio between RRTM max and RRTM min was calculated (Stamatas, Kollias, 2007).

\section{Statistical analysis}

Anisotropy calculated values were statistically analysed using the Kruskal-Wallis test. The other data showing a Gaussian distribution were evaluated by the ANOVA test. The values obtained by the vehicle and formulation with acetyl hexapeptide-3 after 4 weeks were statistically analysed using Mann- Whitney test for nonparametric distribution, and unpaired t- test for parametric distribution. Differences were accepted as statistically significant at $\mathrm{p}<0.05$.

\section{RESULTS AND DISCUSSION}

Acetyl hexapeptide- 3 has been used in anti-aging topical formulations due to its effects in improving the skin appearance (Blanes-Mira et al., 2002; Zhang, Falla, 2009). However there are few basic studies about its effects on skin, as well as, about its mechanism of action. In the present investigation, the efficacy of dermocosmetic formulations containing acetyl hexapeptide-3 was evaluated using biophysical techniques and the capacity of two instruments, the Cutometer ${ }^{\circledR} S E M$ 575 and Reviscometer ${ }^{\circledR} R V 600$, to identify skin changes was compared.

Cutometer ${ }^{\circledR}$ SEM 575 is a non-invasive skinelasticity meter that consists of a microprocessor-regulated pneumatic system that applies suction via a $2-\mathrm{mm}$ circular opening in the handheld probe. Evaluation is based on measurements of skin deformation in response to suction.

The Reviscometer ${ }^{\circledR} R V 600$ is a device equipped with a probe containing two needle-like sensors. When placed on the skin, one needle transmits ultrasound shockwaves and the other is the recipient. The time needed by waves to go from the transmitter to the recipient is the measured RRTM parameter expressed in arbitrary units. The resonance running time measurements (RRTM) of acoustical shockwaves propagates differently through 
the skin according to the state of the elastic fibers and its moisture content (Takema et al., 1994; Hermanns-Lê et al. 2001; Ruvolo, Stamatas, Kollias, 2007).

Age-related cutaneous changes, such as wrinkles and skin laxity, are especially prominent on the facial skin, so several studies have used this site to evaluate the efficacy of cosmetic products (Takema et al., 1994; Sommerfeld, 2007). On the other hand, the ventral forearm, which has limited exposure to sunlight and is an easier site for measurements, has also been used to evaluate changes characterizing chronological aging (Sumino et al., 2004). In this study, both regions were used to evaluate the effects of formulations with acetyl hexapeptide-3.

Four weeks after applying formulations on the forearm skin, the stratum corneum water content showed an increasing tendency, not statistically significant, when compared to the baseline values (Figure 1) $(p>0.05)$. On the other hand, formulations with and without acetyl hexapeptide- 3 increased water content of the stratum corneum in the face region $(p<0.01)$, which remained constant until the end of the study (4 weeks) (Figure 1). Thus, vehicle only also increased the stratum corneum water content to appropriate levels of hydration in a normal skin. These results are in line with previous data obtained by this research group, when peptide-containing emulsions were applied on the volunteers forearm skin once, and after a 4-week period the emulsion with or without peptides caused an enhanced skin hydration (Anconi, Campos, 2008). Skin hydration is an important parameter to evaluate the efficacy of a substance. Moisturizing products may prevent skin alterations resulting from aging and may be used as support in the treatment of several skin diseases (Rawlings, Harding, 2004).

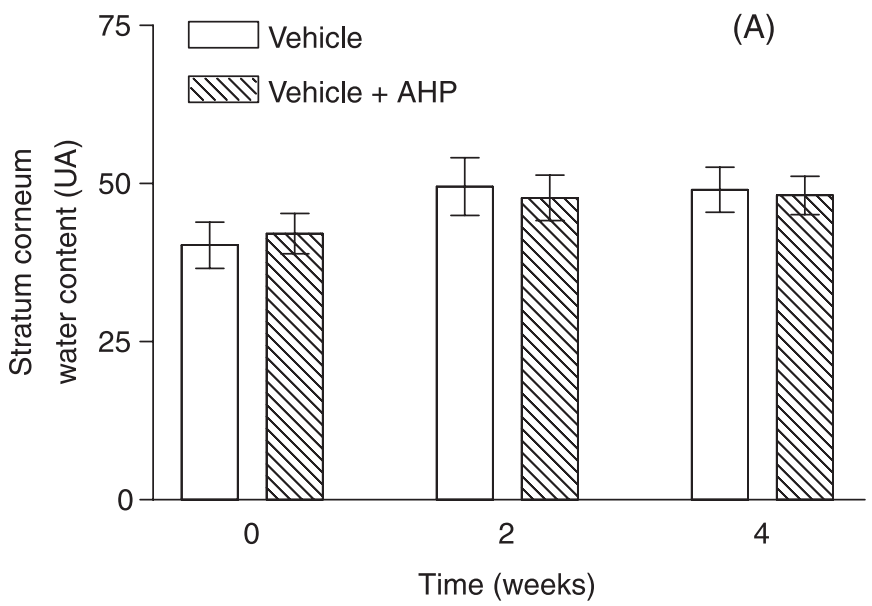

Corneometer ${ }^{\mathbb{B}}$ CM 825 is a device which determines the water content of superficial epidermal layers down to a depth of about $0.1 \mathrm{~mm}$ and expresses the values obtained in arbitrary units (Dal'Belo, Gaspar, Maia Campos, 2006; Fluhr, Gloor, Lazzerini, 1999; Fluhr et al., 1999). Our results showed that acetyl hexapeptide-3 did not increase stratum corneum water content, compared to the vehicle. The vehicle formulation is composed by emollients that can act on superficial moisturizing and acetyl hexapeptide- 3 may effectively contribute to hydration of deeper layers of epidermis, which is not measured by this technique.

In the study of mechanical properties, we compared the ability of two instruments, the Reviscometer ${ }^{\mathbb{B}}$ RVM600 and the Cutometer ${ }^{\circledR}$ SEM 575, to detect skin surface mechanical changes.

Data on shear wave propagation, obtained by the Reviscometer, are shown in Figures 2 to 5 and indicate that acetyl hexapeptide- 3 exhibits a significant effect by decreasing the anisotropy property of face skin. Compared to the vehicle, this reduction was also significant on the face after 4 weeks (Figure 5B). Such a finding suggests increased firmness or tensor effect, since the speed of shear wave propagation on the skin surface is directly proportional to its stiffness (Ruvolo, Stamatas, Kollias, 2007; Vexler, Polyansky, Gorodetsky, 1999). In rigid skin the time for wave spreading will be short, anisotropy and RRTM values smaller (Nizet, Pierard-Franchimont, Pierard, 2001; Verhaegen et al., 2010).

Ruvolo, Stamatas and Kollias (2007) and HermannsLê et al. (2001) observed that while the minimum RRTM values remained fairly constant for the different age groups, the maximum RRTM values increased with age.

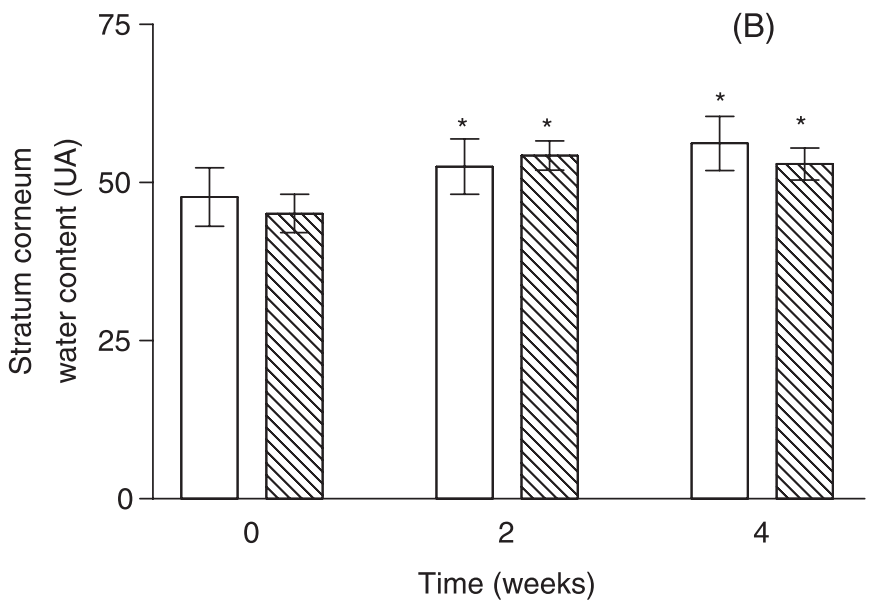

FIGURE 1 - Skin stratum corneum water content before and after a 2 and 4-week long application of test formulations (vehicle, vehicle + acetyl hexapeptide-3) on the forearm (A) and face area (B) of volunteers. AHP: acetyl hexapeptide-3. *Significantly different from the baseline values $(\mathrm{p}<0.01)$. 

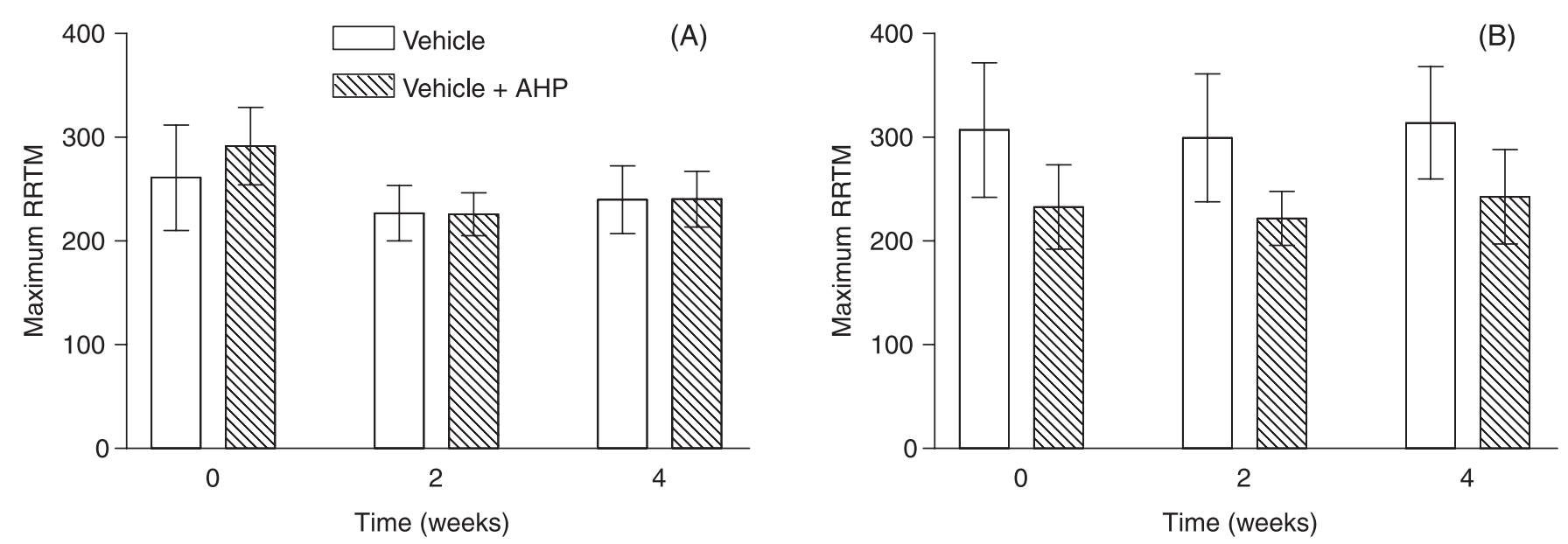

FIGURE 2 - Maximum RRTM before and after a 2 and 4-week long application of test formulations (vehicle, vehicle + acetyl hexapeptide-3) on the forearm (A) and face area (B) of volunteers. AHP: acetyl hexapeptide-3.
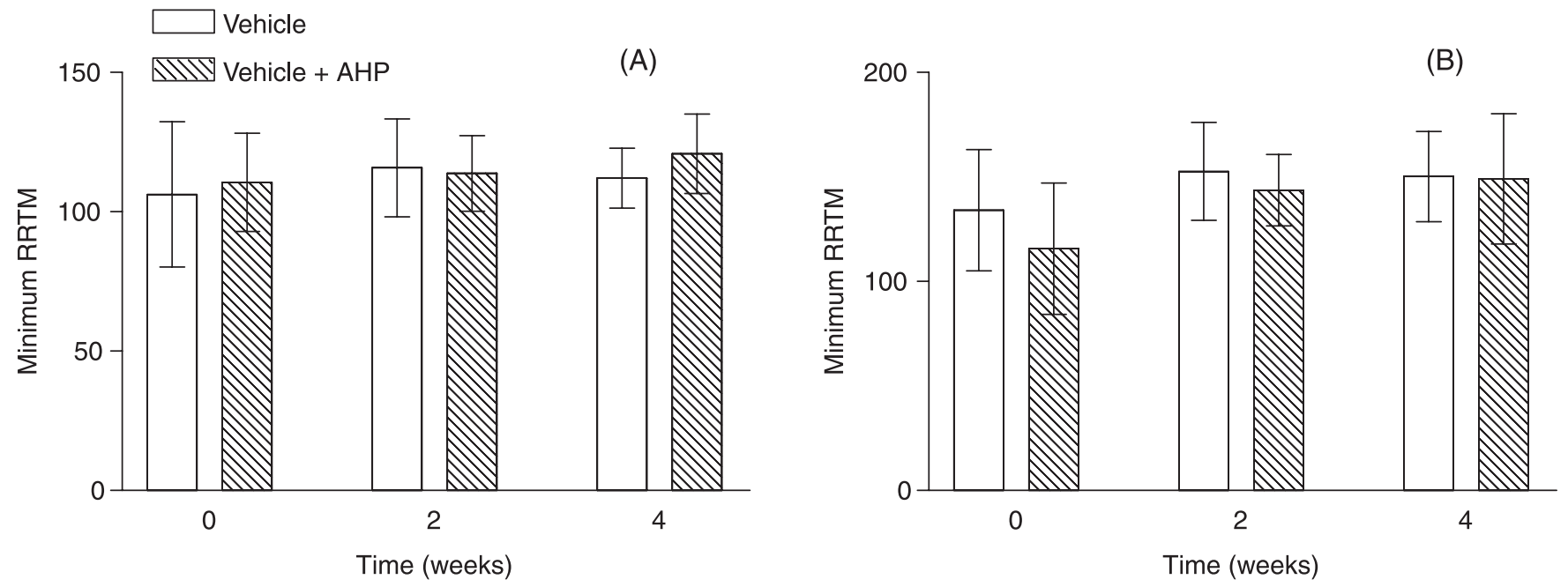

FIGURE 3 - Minimum RRTM before and after a 2 and 4-week long application of the test formulations (vehicle, vehicle + acetyl hexapeptide-3) on the forearm (A) and face area (B) of volunteers. AHP: acetyl hexapeptide-3.
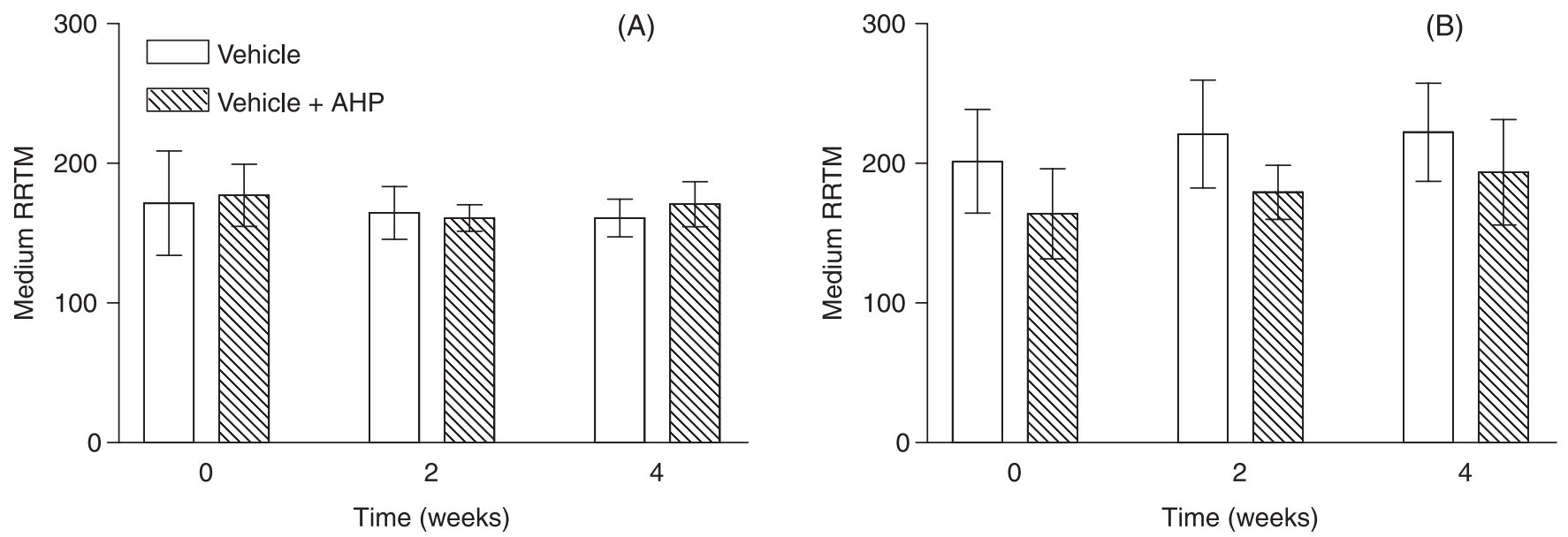

FIGURE 4 - Medium RRTM before and after a 2 and 4-week long application of the test formulations (vehicle, vehicle + acetyl hexapeptide-3) on the forearm (A) and face area (B) of volunteers. AHP: acetyl hexapeptide-3. 

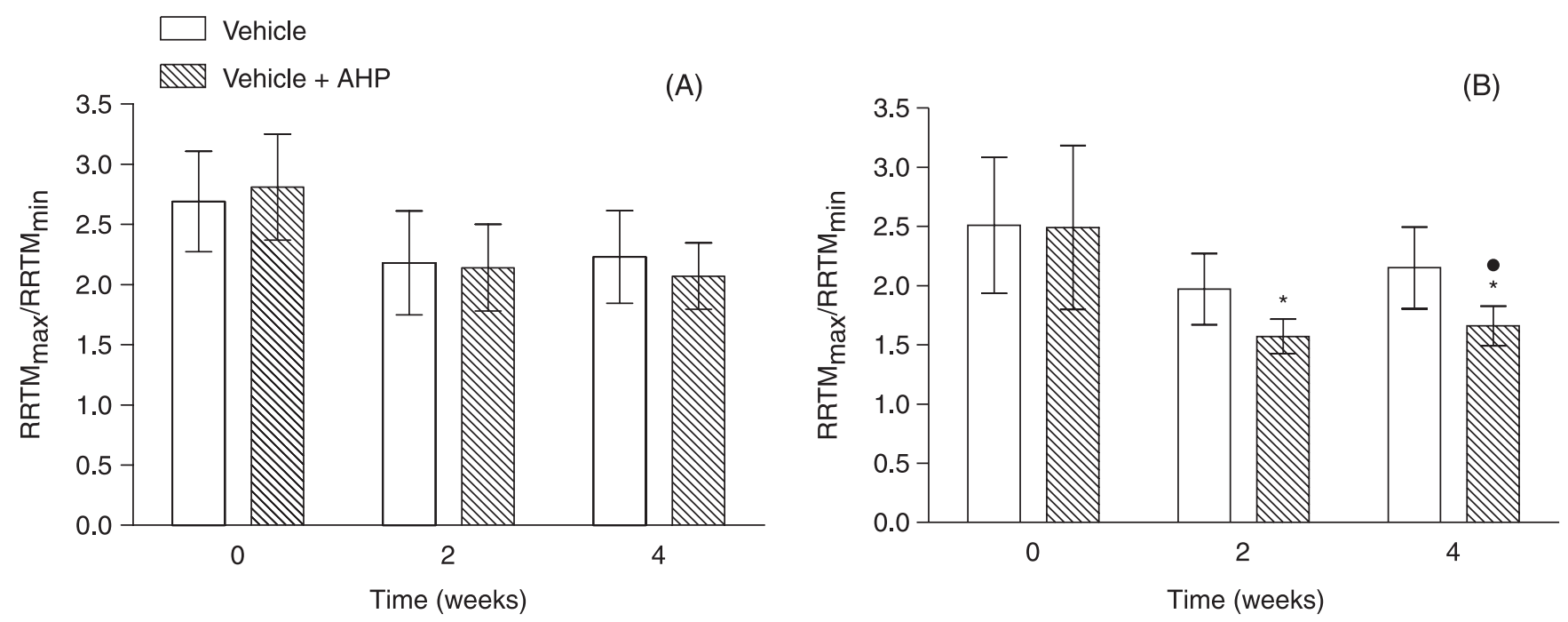

FIGURE 5 - Anisotropy $\left(\mathrm{RRTM}_{\text {maximum }} / \mathrm{RRTM}_{\text {minimum }}\right)$ before and after a 2 and 4-week long application of the test formulations (vehicle, vehicle + acetyl hexapeptide-3) on the forearm (A) and face area (B) of volunteers. AHP: acetyl hexapeptide-3. *Significantly different from baseline values; • Significantly different from Vehicle after 4 weeks using the formulations.

Thus, anisotropy is defined as the ratio between maximum and minimum RRTMs and will also increase with age.

In contrast, in this study, the mean, maximum and minimum RRTM did not show alterations after treatment with formulations tested, meaning that they were less discriminatory between formulations when compared with anisotropy values.

It is concluded that acetyl hexapeptide- 3 is an effective anti-aging compound as already mentioned by Blanes-Mira et al. (2002). The author, using silicone replicas, observed that topical application of an emulsion containing the peptide attenuated the depth of wrinkles in the periocular region after 30 days of treatment, when compared with the vehicle.

Unlike the results on the face region, formulations applied on the forearm did not cause any significant change in the skin anisotropy, suggesting that the effects of the cosmetic formulations in the two regions studied are different, the same as occurred in the determination of stratum corneum water content. This is due to the fact that face and forearm skin have quite different characteristics. The face is more vulnerable to photoaging than the forearms and more susceptible to the action of antiaging products (Blinchmann, Serup, 1988). According to Blinchmann and Serup (1988) and Rogiers (1990), variations in the skin characteristics in different regions of the body may also be related to differences in the stratum corneum thickness and the number and activity of sebaceous glands.

Skin elasticity parameters were not significantly altered, after a 4-week period of daily application of formulations on both skin regions (Figures 6 and 7) as indicated by the lack of changes in the Cutometer $^{\circledR}$ measured elasticity index. Thus, it is possible to conclude that the Reviscometer was better qualified to detect statistically significant effects of acetyl hexapeptide-3 than the Cutometer. Paye et al. (2007) also noted that Reviscometer is able to better discriminate different treatments than the Cutometer, in a study involving induced slight xerotic skin conditions.

In a previous retinoids efficacy study of our research group we observed that dermocosmetic formulations containing retinoic acid altered the skin anisotropy after a 4-week period of daily applications, but these formulations did not alter the cutometer parameters. However, after a 8-week period of daily application, it was possible to detect alterations not only in skin anisotropy but also in cutometer parameters $(\mathrm{Ua} / \mathrm{Uf}$ - the ratio of total retraction to total distension and $\mathrm{Ur} / \mathrm{Uf}$ - the ratio of immediate retraction to total distension) (unpublished data). These observations suggest that significant changes in skin elasticity may occur later or these changes have to attain a certain level to be detected by the Cutometer .

Finally, it is necessary to consider that loss of skin elasticity is one of the main problems of aging and this is a mechanical property influenced by elastin, which together with collagen and glycosaminoglycans make up the connective tissue. As a large number of events cause cutaneous aging (Rieger, 1996), the use of active ingredients that are able to induce alterations in skin mechanical properties is a valid option for the improvement of skin conditions. In this context, the effects of acetyl hexapeptide- 3 on the anisotropy of face skin, 

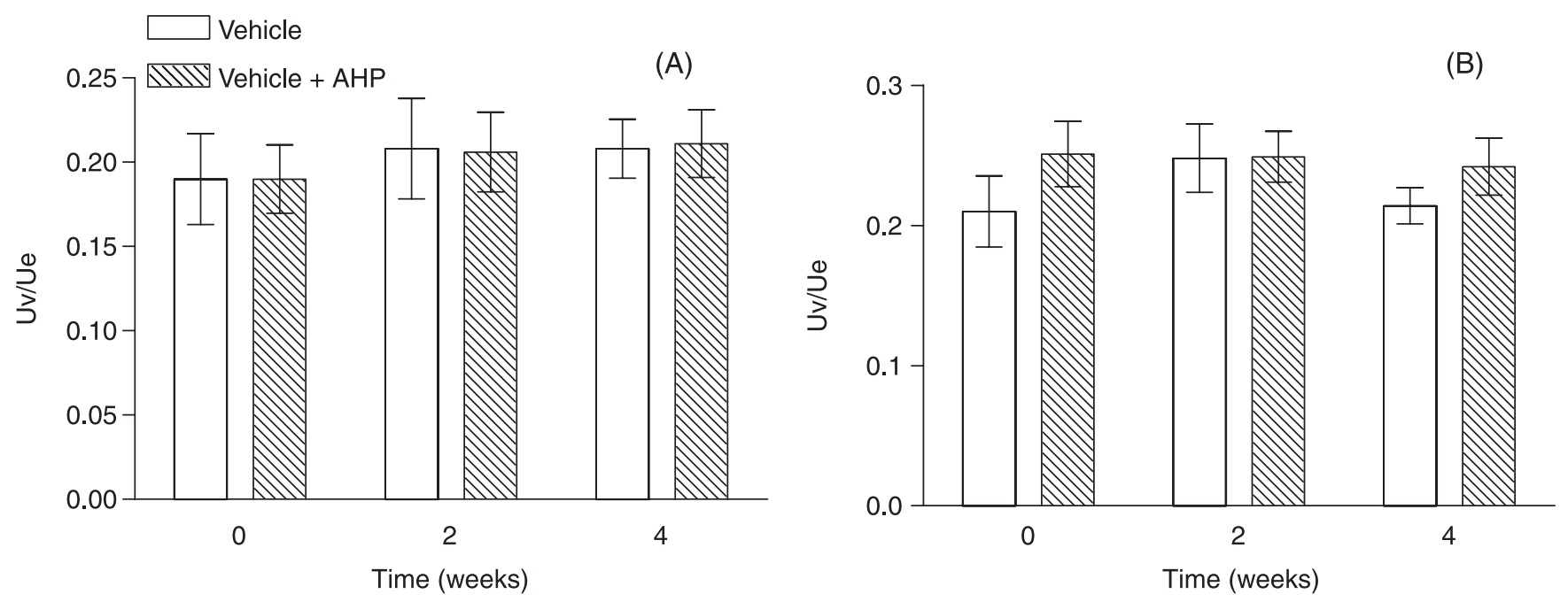

FIGURE 6 - Skin elasticity (Uv/Ue: ratio of delayed distension to immediate distension ) before and after a 2 and 4-week long application of the test formulations (vehicle, vehicle + acetyl hexapeptide-3) on the forearm (A) and face area (B) of volunteers. AHP: acetyl hexapeptide-3.
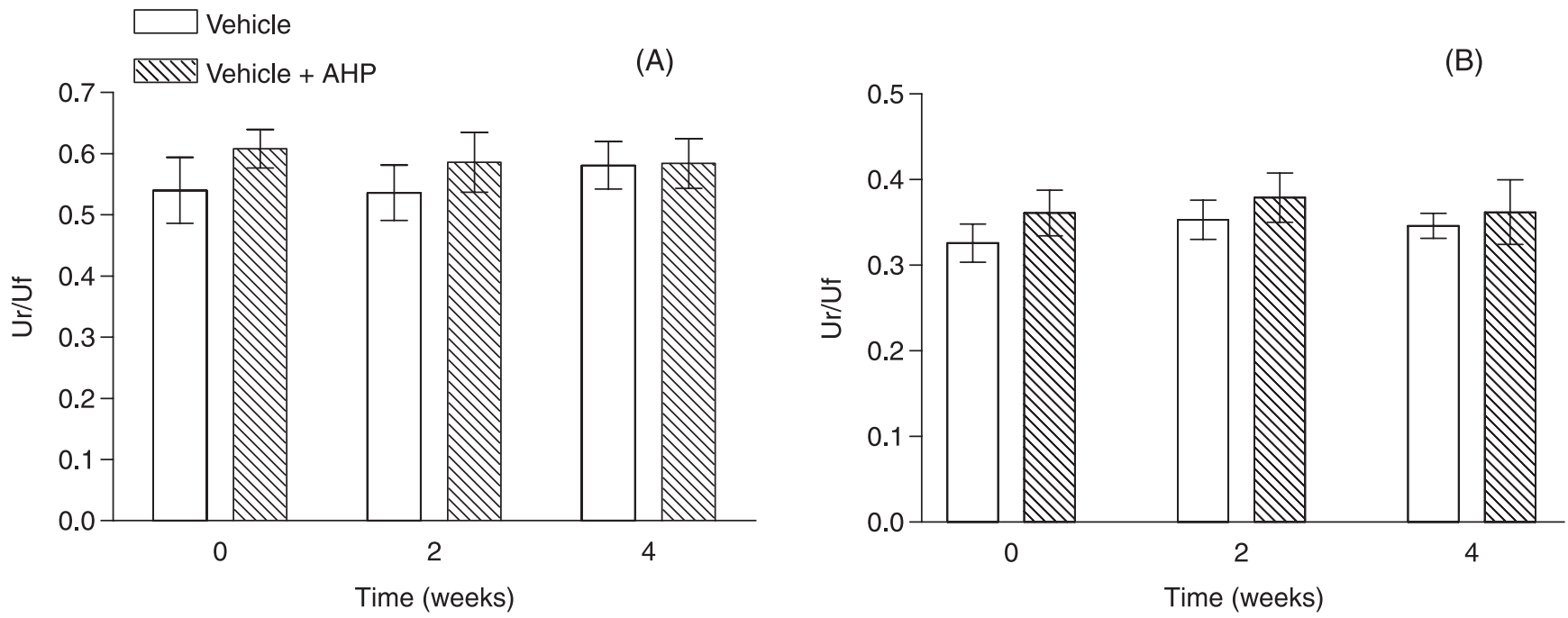

FIGURE 7 - Skin elasticity (Ur/Uf - ratio of immediate retraction to total distension) before and after a 2 and 4-week long application of the test formulations (vehicle, vehicle + acetyl hexapeptide-3) on the forearm (A) and face area (B) of volunteers. AHP: acetyl hexapeptide-3.

characterizes the compound as an effective ingredient for improving conditions of the cutaneous tissue, when used in anti-aging cosmetic formulations.

\section{CONCLUSIONS}

In this study, acetyl hexapeptide- 3 was found to be an effective ingredient for use in anti-aging cosmetic formulations due to its reduction of the anisotropy of face skin and probable action on its mechanical properties. This way, it can be used in cosmetic formulations to prevent skin alterations, premature aging and improve skin conditions.

\section{DISCLOSURES}

On behalf of all authors, the corresponding author states that there is no conflict of interest. The authors gratefully acknowledge the financial support of São Paulo Research Foundation (FAPESP).

\section{REFERENCES}

ANCONI, G.L.; CAMPOS, P.M.B.G.M. Stability and clinical efficacy of cosmetic formulations containing different peptides. In: IFSCC CONGRESS, 25., 2008. Barcelona: Luton: IFSCC, 2008. 
BLANES-MIRA, C.; CLEMENTE, J.; JODAS, G.; GIL, A.; FERNÁNDEZ-BALLESTER, G.; PONSATI, B.; GUTIERREZ, L.; PÉREZ-PAYÁ, E.; FERRERMONTIEL, A. A synthetic hexapeptide (Argireline) with antiwrinkle activity. Int. J. Cosmet. Sci., v.24, n.5, p.303310, 2002.

BLINCHMAN, C.W.; SERUP, J. Assessment of skin moisture: measurement of electrical conductance, capacitance and transepidermal water loss. Acta Derm. Venereol., v.68, n.4, p.284-290, 1988.

DAL'BELO S.E.; GASPAR, L.R.; MAIA CAMPOS P.M.B.G. Moisturizing effect of cosmetic formulations containing Aloe vera extract in different concentrations assessed by skin bioengineering techniques. Skin Res. Technol., v.12, n.4, p.241-246, 2006.

DOBREV, H,P. Use of Cutometer to assess epidermal hydration. Skin Res. Technol., v.6, p.239-244, 2000.

DOBREV, H.P. A study of human skin mechanical properties by means of Cutometer. Folia Medica (Plovdiv), v.44, n.3, p.5-10, 2002 .

FLUHR, J.W.; GLOOR, M.; LAZZERINI, S. Comparative study of five instruments measuring stratum corneum hydration (Corneometer CM820 and CM825, Skicon200, Nova DPM9003, DermaLab). Part 1. In vitro. Skin Res. Technol., v.5, n.3, p.161-170, 1999.

FLUHR, J.W.; GLOOR, M.; LAZZERINI, S.; KLEESZ, P., GRIESHABER, R. AND BERARDESCA, E. Comparative study of five instruments measuring stratum corneum hydration (Corneometer CM820 and CM825, Skicon200, Nova DPM9003, DermaLab). Part 2. In vivo. Skin Res. Technol., v.5, n.3, p.171-178, 1999.

HAFTEK M, MAC-MARY S, LE BITOUX MA, CREIDI P, SEITÉ S, ROUGIER A, HUMBERT P. Clinical, biometric and structural evaluation of the long-term effects of a topical treatment with ascorbic acid and madecassoside in photoaged human skin. Exp. Dermatol., v.7, n.11, p.946952, 2008.

HERMANNS-LÊ, T.; JONLETA, F.; SCHEENB, A.; PIÉRARD G.E. Age- and body mass index-related changes in cutaneous shear wave velocity. Exp. Gerontol., v.36, n.2, p.363-372, 2001.
NIZET, J.L.; PIERARD-FRANCHIMONT, C.; PIERARD, G.E. Influence of the body posture and gravitational forces on shear wave propagation in the skin. Dermatology, v.202, n.2, p.177-180, 2001.

PAYE M.; MAC-MARY, S.; ELKHYAT, A.; TARRIT, C.; MERMET, P.; HUMBERT P.H. Use of the Reviscometer for measuring cosmetics-induced skin surface effects. Skin Res. Technol., v.13, n.4, p.343-349, 2007.

RAWLINGS, A.V.; HARDING, C.R. Moisturization and skin barrier function. Dermatol. Ther., v.17, Supl.1, p.43-48, 2004.

RIEGER, M. Ceramides their promise in skin care. Cosm. Toil., v.111, p.33-45, 1996.

ROGIERS, V. Standardized conditions needed for skin surface hydration measurements. Cosm. Toil., v.105, p.76-82, 1990.

RUVOLO, E.C.; STAMATAS, G.N.; KOLliAS, N. Skin viscoelasticity displays site- and age- dependent angular anisotropy. Skin Pharmacol. Physiol., v.20, n.6, p.313-321, 2007.

SAVICA, S.; TAMBURIC, S.; SAVIC, M.; CEKIC, N.; MILIC, J.; VULETA, G. Vehicle-controlled effect of urea on normal and SLS-irritated skin. Int. J. Pharm., v.271, n.1-2, p.269$280,2004$.

SIVILIA, S.; PARADISI, M.; D'INTINO, G.; FERNANDEZ, M.; PIRONDI, S,; LORENZINI L, CALZA L. Skin homeostasis during inflammation: a role for nerve growth factor. Histol. Histopathol., v.23, p.1-10, 2008.

SOMMERFELD B. Randomised, placebo-controlled, doubleblind, split-face study on the clinical efficacy of Tricutan on skin firmness. Phytomedicine, v.14, n.11, p.711-715, 2007.

SUMINO, H.; ICHIKAWA, S.; ABE, M.; ENDO, Y.; ISHIKAWA, O.; URABAYASHI M. Effects of aging, menopause and hormone replacement therapy on forearm skin elasticity in women. J. Am. Geriatr. Soc., v.52, n.6, p.945-949, 2004.

TAKEMA, Y.; YORIMOTO, Y.; KAWAI, M.; IMOKAWA, G. Age-related changes in the elastic properties and thickness of human facial skin. Br. J. Dermatol., v.131, n.5, p.641648, 1994. 
UHODA, I.; FASKA, N.; ROBERT, C.; CAUWENBERGH, G.; PIÉRARD, G.E. Split face study on the cutaneous tensile effect of 2-dimethylaminoethanol (deanol) gel. Skin Res. Technol., v.8, n.3, p.164-167, 2002.

VERHAEGEN, P.D.; RES, E.M.; VAN ENGELEN, A.; MIDDELKOOP. E.; VAN ZUIJLEN P.P. A reliable,noninvasive measurement tool for anisotropy in normal skin and scar tissue. Skin Res. Technol., v.16, n.3, p.325-331, 2010.
VEXLER, A.; POLYANSKY, I.; GORODETSKY, R. Evaluation of skin viscoelasticity and anisotropy by measurement of speed of shear wave propagation with viscoelasticity skin analyzer. J. Investig. Dermatol., v.113, n.5, p.732-739, 1999.

ZHANG, L.; FALLA, T.J. Cosmeceuticals and peptides. Clin. Dermatol., v.27, n.5, p.485-494, 2009.

Received for publication on $20^{\text {th }}$ November 2014 Accepted for publication on $02^{\text {nd }}$ July 2015 
